\title{
Maidontuotannon vakavien vaikeuksien tuki
}

\author{
Jukka Pekonniemi $^{1)}$, Timo Karhula ${ }^{2}$ ja Matti Ylätalo ${ }^{3)}$ \\ 1) Maa-ja metsätalousministeriö, PL 30, 00023 Valtioneuvosto \\ jukka.pekonniemi@mmm.fi \\ 2) MTT Taloustutkimus, Luutnantintie 13, PL 3, 00411 Helsinki, \\ timo.karhula@mtt.fi \\ 3) Helsingin yliopisto, Taloustieteen laitos, PL 27, 00014 Helsingin yliopisto \\ matti.ylatalo@helsinki.fi
}

\section{Johdanto}

Suomen Euroopan unionin liittymissopimukseen sisällytettiin Etelä-Suomen osalta 141-artikla eli vakavien vaikeuksien tukea koskeva artikla. Artikla mahdollistaa kansallisen tuen maksamisen kotieläin- ja puutarhataloudelle, jos muiden tukimuotojen soveltamisen jälkeen sopeutumisesta EU:n yhteiseen maatalouspolitiikkaan aiheutuu edelleen vakavia vaikeuksia. Artikla 141 ei sinällään määrittele vakavia vaikeuksia, tuen kestoaikaa, tukitasoja tai tukien maksuperusteita, joten niistä on neuvoteltava määräajoin komission kanssa.

Etelä-Suomessa 141-tukialueella on noin 5000 maitotilaa, joilla tuotetaan noin $25 \%$ koko Suomen maitomäärästä. Maitotilojen määrä on viime vuosina vähentynyt, mutta tuotetun maidon määrä ei ole vähentynyt vastaavasti tilakoon kasvun ja lehmien tuotostason nousun johdosta. Maidontuotanto on kuitenkin edelleen Etelä-Suomessa merkittävä työllistäjä kerrannaisvaikutuksineen. Monivaikutteisuutensa vuoksi maidontuotanto vaikuttaa maaseudun elinvoimaisuuteen ja tuottaa maisema-arvoja. Siten eteläsuomalainen maidontuotanto on arvokas yritystoiminnan muoto.

Suomen pohjoisesta sijainnista aiheutuvat pysyvät luonnonolosuhteet aiheuttavat maidontuotannolle lisäkustannuksia, jolloin maidon tuotantokustannukset muodostuvat korkeiksi. Maidontuotannon kannattavuus jääkin nykyisillä tuotehinnoilla ja tukitasoilla heikoksi. Tukimuodoista erityisesti 141-tuella on merkittävä vaikutus maitotilojen kannattavuuteen ja siten eteläsuomalaisen maidontuotannon jatkuvuuteen.

\section{Tutkimuksen aineisto ja menetelmät}

Tämän tutkimuksen tavoitteena oli Etelä-Suomessa 141-tukialueella toimivien maitotilojen tuloksen ja kannattavuuden selvittäminen sekä 141-tuen tarpeen arviointi. Lisäksi tarkasteltiin maitotilojen reaaliprosessia. Sen avulla selvitettiin taloudellisten tunnuslukujen taustalla olevia tekijöitä, jotka eivät näy rahaprosessin tunnusluvuista. Lehmien rehustukseen, ruokintaan ja teknologiaan liittyviä maidontuotannon erityispiirteitä Suomessa selvitettiin kahden asiantuntijapaneelin avulla.

Tutkimusaineistona käytettiin MTT Taloustutkimuksen Etelä-Suomen kannattavuuskirjanpitoaineistoa. Tutkimustiloilla oli keskimäärin 18 lypsylehmää ja tilojen peltopinta-ala oli noin 36 hehtaaria. Tiloilla tehtiin keskimäärin 4600 työtuntia ja yrittäjien keski-ikä oli 48 vuotta vuonna 2000 . Aineisto ja siitä lasketut tulokset painotettiin vastaamaan kaikkia Etelä-Suomessa toimivia maitotiloja. 


\section{Tulokset ja tulosten tarkastelu}

Suomen luonnonolosuhteet poikkeavat huomattavasti Keski-Euroopan olosuhteista. Luonnonolosuhteet aiheuttavat suomalaisille maitotiloille monia lisäkustannuksia. Haitat ovat pysyviä ja tilakoon kasvulla näitä kustannuksia ei voida kokonaan poistaa. Esimerkiksi kasvukausi on maassamme lyhyt, jolloin suotuisa kylvö- ja korjuukausi jää väistämättä lyhyeksi. Viljelypinta-alaan nähden tarvitaan tällöin suhteessa tehokkaampia ja samalla kalliimpia koneita. Lisäksi alhaisen tehoisan lämpötilasumman vuoksi kasvilajija lajikevalikoima on niukka ja viljelysmaan laatu sekä sadannan epätasainen jakautuminen heikentävät satotasoja ja toisinaan myös sadon laatua Suomessa.

Lyhyt kasvukausi vaikuttaa suoraan laidunkauden pituuteen. Suomen lyhyen laidunkauden vuoksi lehmien vuotuisesta energiantarpeesta pienempi osa saadaan laitumelta kuin Keski-Euroopassa, jolloin säilörehua joudutaan varastoimaan Suomessa huomattavasti enemmän. Suomalainen nurmisäilörehu ei ole korkeiden tuotantokustannuksien vuoksi läheskään yhtä kilpailukykyinen karkearehu kuin maissi KeskiEuroopassa.

Maitotilojen rakenteen kehittämistä maassamme vaikeuttavat luonnonolosuhteiden lisäksi maatilojen epäedullinen sisäinen ja ulkoinen liikenneasema, kuten esimerkiksi peltoaukeiden pienuus, peltokuvioiden pirstaleisuus ja pitkät välimatkat tuotteiden ja panosten myynti- ja ostopaikkoihin nähden, jolloin maitotilojen reaaliprosessi on monella tapaa erilainen Keski-Eurooppaan verrattuna. Lisäksi kylmyys rajoittaa tuotannon automatisointia ja uudet investoinnit ovat yleensä sidoksissa vanhaan tuotantotekniikkaan. Kylmät talvet edellyttävät lisärakenteita ja muutoksia tuotantorakennuksiin ja -koneisiin, jotka työvoimatarpeen kausiluonteisuuden lisäksi aiheuttavat ongelmia ja lisäkustannuksia.

Etelä-Suomen maitotiloilla kokonaistuotot olivat keskimäärin 82700 euroa vuonna 2000 (kuvio 1). Myyntituloja oli keskimäärin $62 \%$, tukia $33 \%$ ja muita tuloja $5 \%$ kokonaistuotosta. Samaan aikaan maitotilojen keskimääräiset kokonaiskustannukset olivat noin 101000 euroa tilaa kohti. Eri kululajien suhteelliset osuudet kokonaiskustannuksesta olivat seuraavat: muuttuvat kulut $29 \%$, yrittäjäperheen palkkavaatimus $34 \%$, poistot $14 \%$, muut kiinteät kulut $11 \%$ sekä oman pääoman korkovaatimus ja rahoituskulut $12 \%$.

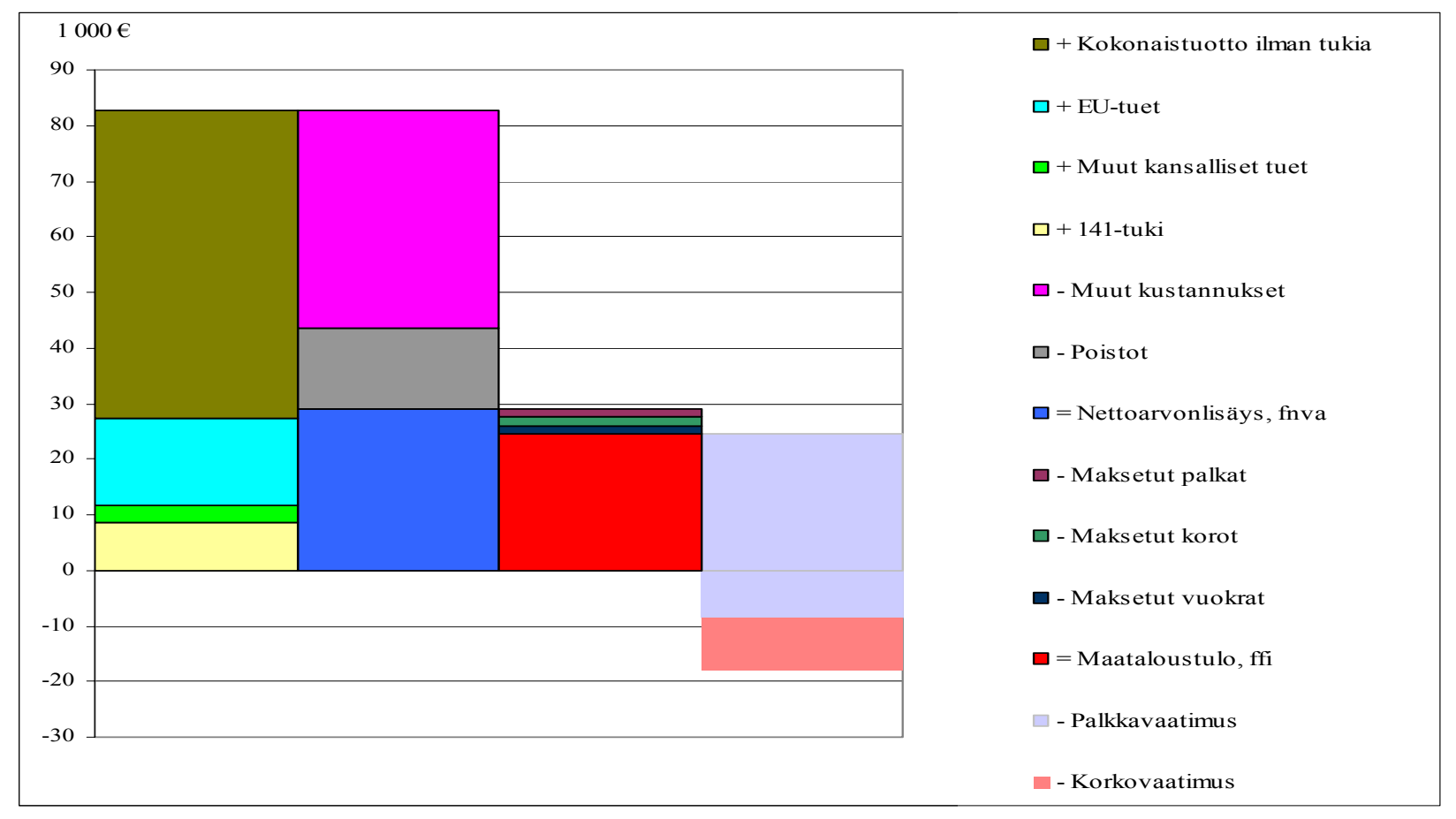

Kuvio 1. Maidontuotantotilojen tuotto- ja kustannusrakenne Etelä-Suomessa vuonna 2000. 
Vuonna 2000 eteläsuomalaisilla maitotiloilla saavutettiin kannattavuuskertoimella arvioiden vain noin 58 $\%$ asetetuista yrittäjäperheen palkka- ja oman pääoman korkotavoitteista. Tämä merkitsee sitä, että yrittäjä saa tekemälleen työlle 4,4 euron tuntipalkan ja 2,9 \%:n koron omalle pääomalle. Tällöin ei ole saavutettu yritystoiminnalle asetettuja taloudellisia tavoitteita, jolloin maitotiloille on aiheutunut yrittäjäntappiota. Yrittäjäntappio oli vuonna 2000 keskimäärin -18 600 euroa tilaa kohden.

Tarkasteltaessa eteläsuomalaisia maitotiloja karjakokoluokittain tuloskäsitteistä nettoarvonlisäys ja maataloustulo kasvavat absoluuttisesti suurempiin karjakokoluokkiin siirryttäessä. Vaikka maitotilojen tulos pääsääntöisesti paranee suurempiin karjakokoluokkiin siirryttäessä, tulos ei kuvaa kannattavuuden paranemista (kuvio 2). Maidontuotannon kannattavuus nousee lievästi kannattavuuskertoimella mitattuna toiseksi suurimpaan kokoluokkaan asti, mutta vastoin odotuksia kannattavuus jää suurimmassa karjakokoluokassa edellistä luokkaa alemmalle tasolle. Vaikka maidontuotannon kannattavuus paranee tiettyyn karjakokoluokkaan saakka, niin tuolloinkaan ei ylletä kannattavuuskertoimen arvoon 1 saakka.

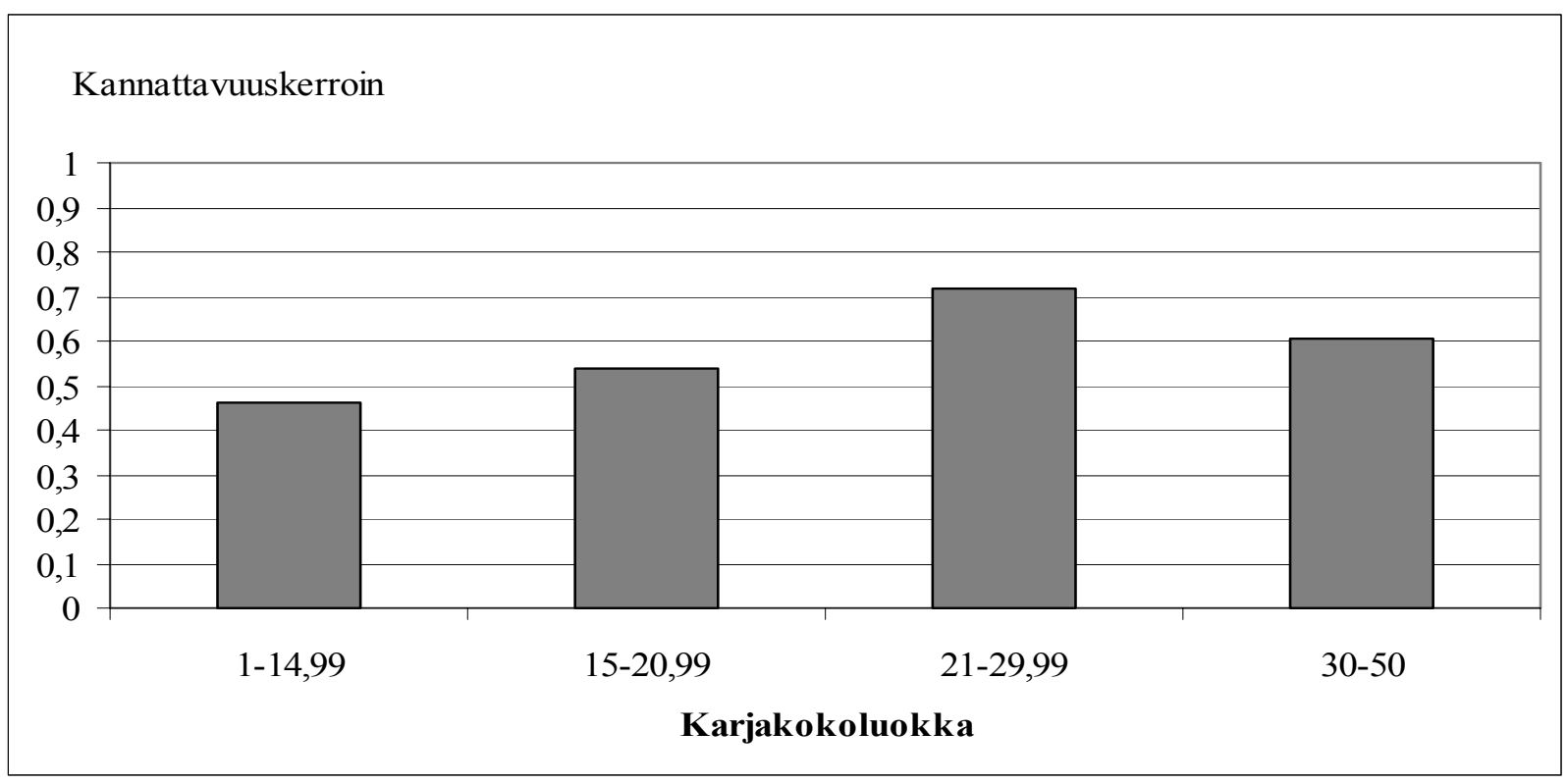

Kuvio 2. Kannattavuuskerroin karjakokoluokittain Etelä-Suomen maitotiloilla vuonna 2000.

Pienten maitotilojen huonoa kannattavuutta selittää osaksi se, että niillä on korkeammat kustannukset yksikköä kohden, mikä näkyy kannattavuuskertoimen tasossa. Koska kannattavuuden mittaaminen perustuu yhden vuoden kirjanpitotilojen tuloksiin, kannattavuuden taso voi olla alhainen myös hiljattain suoritetuista investoinneista johtuen, koska investointien taloudelliset vaikutukset näkyvät vasta vuosien viiveellä, mikä selittää osaltaan suurimman karjakokoluokan kannattavuuden alhaista tasoa.

141- tuen merkitys on suuri eteläsuomalaisille maitotiloille. Sen osuus myyntituottojen ja tukien yhteissummasta oli keskimäärin $10 \%$ ja maataloustulosta peräti $32 \%$ vuonna 2000. Kannattavuuskerroin laskisi noin 0,2 yksikköä ilman 141-tukea, jolloin yrittäjäperheen palkaksi jäävä osa laskisi noin 1,5 euroa työtuntia kohden ja oman pääoman korko $1 \%$ :n. 


\section{Johtopäätökset}

Suomessa yrityskoon kasvattamisella ja tuotannon kehittämisellä ei voida yksistään ratkaista maidontuotannon kannattavuusongelmaa. Luonnonolosuhteista johtuen maidon yksikkökustannukset ovat maassamme keskimääräistä korkeammat ja siten maidontuotannon taloudellinen kilpailukyky on pysyvästi heikompi Keski-Euroopan suotuisempien alueiden maidontuotantoon verrattuna.

Suomessa maidontuotannon yksikkökustannusta voidaan alentaa yrityskokoa kasvattamalla vain tiettyyn rajaan saakka. Tuotantoprosessin hallinnan, panosten oston, tuotteiden markkinoinnin, rahoituksen ja henkilöstön johtamisen vaatimukset ja riskit kasvavat yrityskoon kasvattamisen myötä. Yrittäjän liikkeenjohtoon ja päätöksentekoon liittyvien ongelmien vuoksi maidontuotannon kannattavuus ei enää välttämättä nouse vaan saattaa kääntyä jopa laskuun yrityskokoa kasvatettaessa.

Suomalaiset maitotilat joutuvat kilpailemaan samoilla markkinoilla suotuisempien tuotantoalueiden viljelijöiden kanssa, joiden luonnonolosuhteet taikka tuotantoteknologia eivät ole kuitenkaan siirrettävissä suoraan Suomeen. Esimerkiksi teknologisen kehityksen hyödyntämisessä Keski-Eurooppa on Suomea edellä ja absoluuttinen karjakokoero Suomen ja Keski-Euroopan välillä kasvaa maassamme viime vuosina tapahtuneesta voimakkaasta rakennekehityksestä huolimatta.

Suomessa maidontuotannon kannattavuus on parantunut viime vuosina, mutta ei riittävästi. Positiivinen kannattavuuskehitys tulee arvion mukaan katkeamaan lähivuosina ja kannattavuus alkaa heiketä. Eteläsuomalaisille maitotiloille erityisesti 141-tuki on erittäin merkittävä kannattavuuteen vaikuttava tekijä, joten tuen tasossa tapahtuvat muutokset näkyvät suoraan tilojen kannattavuudessa. Lisäksi vuonna 2003 sovittu EU:n maatalousreformi tulee vaikuttamaan maitotiloille maksettaviin tukiin ja välillisesti markkinahintoihin. Maidontuotantoon kohdistuvat taloudelliset epävarmuustekijät ovat viime aikoina kasvaneet huomattavasti ja tulevat edelleen kasvamaan. 